\title{
IDENTIFIKASI PENYEBAB PENYAKIT DAUN KERITING KUNING PADA TANAMAN MENTIMUN
}

\author{
Dwiwiyati Nurul Septariani, Sri Hendrastuti Hidayat, \& Endang Nurhayati \\ Departemen Proteksi Tanaman, Fakultas Pertanian, Institut Pertanian Bogor \\ Jl. Kamper, Kampus IPB Darmaga Bogor 16680 \\ Telp. 0251-8629364, Faks 0251-8629362 \\ Email: nurulseptariani@gmail.com
}

\begin{abstract}
Identification of the causal agent of yellow leaf curl disease on cucumbers. Yellow leaf curl disease has been reported to cause serious diseases and yield losses on tobacco, chilli pepper, and tomato plants in Java. Similar symptoms were observed recently on cucumber plants from several growing areas in West Java (Bogor), Central Java (Tegal and Sukoharjo), and Yogyakarta (Sleman). Symptom variations including mosaic, chlorotic spotting, leaf curling, blistering, vein banding, reduction and distortion of leaf and fruit were observed. Serological detection using Enzyme Linked Immunosorbent Assay (ELISA) showed infection of several viruses. Antibodies specific to Squash mosaic comovirus (SqMV), Zucchini yellow mosaic potyvirus (ZyMV), dan Cucumber mosaic cucumovirus (CMV) were reacted positively with field samples. No serological reactions were observed with antibodies to Tobacco ringspot potyvirus (TRSV) and Watermelon mosaic potyvirus (WMV). Molecular detection approach based on Polymerase Chain Reaction was undergone using universal primers for Geminivirus, pAL1v1978 and pAR1c715. DNA fragment $1600 \mathrm{bp}$ in size, was successfully amplified from leaf samples originated from Tegal, Sleman, Bogor, and Sukoharjo. Further identification by nucleotide sequencing indicated that virus isolates causing yellow leaf curl disease on cucumber have highest homology (95.7\% to $98.6 \%$ ) with Tomato leaf curl New Delhi virus[Cucumber:Indonesia] (AB613825) from Klaten, Central Java, Indonesia.
\end{abstract}

Key words: ELISA, Geminivirus, polymerase chain reaction, sequence analysis

\begin{abstract}
ABSTRAK
Identifikasi penyebab penyakit daun keriting kuning pada tanaman mentimun. Penyakit daun keriting kuning telah dilaporkan menjadi kendala utama dan menyebabkan kehilangan hasil yang cukup besar pada pertanaman tembakau, cabai, dan tomat di Jawa. Penyakit yang sama ditemukan pada pertanaman mentimun di Jawa Barat (Bogor), Jawa Tengah (Tegal dan Sukoharjo), dan Daerah Istimewa Yogyakarta (Sleman). Variasi gejala yang terdapat di lapangan antara lain gejala mosaik, bintik kuning, mengeriting, melepuh, penebalan tulang daun, reduksi ukuran daun, dan perubahan bentuk buah. Deteksi virus menggunakan metode Enzyme Linked Immunosorbent Assay (ELISA) pada sampel daun mentimun dari lapangan menunjukkan adanya infeksi beberapa virus. Reaksi positif terjadi pada pengujian menggunakan antibodi spesifik Squash mosaic comovirus (SqMV), Zucchini yellow mosaic potyvirus (ZyMV), dan Cucumber mosaic cucumovirus (CMV), sedangkan reaksi negatif terjadi pada antibodi Tobacco ringspot potyvirus (TRSV) and Watermelon mosaic potyvirus (WMV). Deteksi molekuler dilakukan dengan metode Polymerase Chain Reaction (PCR) menggunakan primer universal untuk Geminivirus, pAL1v1978 dan pAR1c715. Pita DNA berukuran 1600 pasang basa berhasil teramplifikasi dari sampel daun asal Tegal, Sleman, Bogor, dan Sukoharjo. Hasil perunutan basa nukleotida menunjukkan bahwa Geminivirus penyebab penyakit mosaik keriting kuning mentimun adalah Tomato leaf curl begomovirus (TLCV). Isolat-isolat TLCV dari Tegal, Sleman (Kalasan dan Ngemplak), Sukoharjo, dan Bogor memiliki homologi paling tinggi yaitu sebesar 95.7\% hingga 98.6\%, dengan Tomato leaf curl New Delhi virus-[Cucumber:Indonesia] (AB613825) asal Klaten.
\end{abstract}

Kata kunci: Analisis sikuen, ELISA, Geminivirus, polymerase chain reaction

\section{PENDAHULUAN}

Penyakit daun keriting kuning yang disebabkan oleh anggota Begomovirus pada beberapa tanaman di
Indonesia dilaporkan menyebabkan kerugian dan kehilangan hasil yang cukup besar. Pertanaman tembakau di Jawa Timur terinfeksi Tobacco leaf curl begomovirus sejak tahun 1984 dan menyebabkan 
kerusakan sebesar 30\% dari seluruh areal pertanaman (Trisusilowati et al., 1990). Kejadian penyakit yang disebabkan Tomato yellow leaf curl virus (TYLCV) mencapai $50-70 \%$ sehingga menjadi kendala utama dalam meningkatkan produksi tanaman tomat terutama di Jawa Barat dan Jawa Tengah (Aidawati et al., 2005; Santoso et al., 2008). Infeksi Begomovirus paling parah terjadi pada tanaman cabai di daerah Jawa Barat sejak tahun 1999 yang disebabkan oleh Pepper yellow leaf curl virus (PYLCV). Keterjadian penyakit daun keriting kuning cabai mencapai $100 \%$ dan epidemi penyakit terjadi di sentra-sentra produksi cabai di Indonesia terutama di Pulau Jawa pada tahun 2000 sampai 2003 (Hidayat et al., 2006).

Penyakit daun keriting kuning telah dilaporkan menyebabkan kerugian hasil pada tanaman Cucurbitaceae di Thailand (Ito et al., 2008). Penyakit ini berasosiasi dengan Squash leaf curl China virus dan menyerang tanaman labu (Cucurbita pepa L.). Tanaman mentimun ditemukan menunjukkan gejala penyakit daun menguning yang parah sejak tahun 1996. Samretwanich et al. (2000a, 2000b, 2000c) berhasil mendeteksi Begomovirus dan mendapatkan urutan nukleotida Begomovirus dari tanaman mentimun, melon (Cucumis melo L.), cantaloupe (Cucumis melo var. reliculatus) dan wax gourd (Benincase hispida Cogn.).

Mizutani et al. (2011) melaporkan bahwa akhirakhir ini ditemukan adanya penyakit daun keriting yang terdapat pada tanaman mentimun di Indonesia yaitu di Kabupaten Klaten, Jawa Tengah. Tanaman mentimun tersebut menunjukkan gejala daun keriting, mosaik hijau kekuningan dan perubahan bentuk buah sehingga menyebabkan kerugian bagi para petani. Identifikasi molekuler menunjukkan penyakit tersebut disebabkan oleh kelompok Begomovirus. Gejala yang sama ditemukan pada pertanaman mentimun di beberapa daerah di Jawa Barat, Jawa Tengah, dan Daerah Istimewa Yogyakarta. Identifikasi molekuler Begomovirus yang menginfeksi tanaman mentimun tersebut dilaporkan pada artikel ini.

\section{METODE PENELITIAN}

Tempat dan Waktu. Penelitian ini dilaksanakan di Laboratorium Virologi Tumbuhan Departemen Proteksi Tanaman, Fakultas Pertanian, Institut Pertanian Bogor, mulai bulan Maret 2012 sampai Februari 2013.

Pengumpulan Sampel Tanaman Mentimun Terinfeksi Begomovirus. Pengamatan gejala dan pengambilan sampel tanaman dilakukan di beberapa pertanaman mentimun. Propinsi Jawa Barat yaitu Kabupaten Bogor (Kecamatan Situgede) dan Kabupaten Subang (Kecamatan Kasomalang dan Pagaden Barat); Propinsi Jawa Tengah yaitu Kabupaten Tegal (Kecamatan Dukuhwaru) dan Kabupaten Sukoharjo (Kecamatan Baki); di Daerah Istimewa Yogyakarta yaitu Kabupaten Sleman (Kecamatan Kalasan dan Ngemplak). Daun mentimun yang dikumpulkan sebagai sampel adalah daun yang berasal dari tanaman yang menunjukkan gejala keriting, melepuh, dan menguning. Sebagian dari sampel daun disimpan di dalam deep freezer pada suhu $-80{ }^{\circ} \mathrm{C}$ dan sebagian lagi dikeringawetkan dengan silica gel sebelum digunakan untuk tahapan identifikasi. Deteksi dan identifikasi virus dilakukan di Laboratorium Virologi Tumbuhan, Departemen Proteksi Tanaman, Fakultas Pertanian, Institut Pertanian Bogor.

\section{Deteksi Beberapa Virus pada Sampel Daun dari Lapangan}

\section{Deteksi Menggunakan Enzyme Linked} Immunosorbent Assay (ELISA). Deteksi virus dilakukan dengan metode ELISA karena spesifikasi, kecepatan, bersifat kuantitatif, dan memiliki sensitivitas tinggi (Clark \& Adams, 1977). Deteksi dilakukan menggunakan beberapa antiserum yaitu antiserum untuk Squash mosaic comovirus (SqMV), Zucchini yellow mosaic potyvirus (ZyMV), Cucumber mosaic cucumovirus (CMV), Tobacco ringspot potyvirus (TRSV), dan Watermelon mosaic potyvirus (WMV). Metode ELISA yang digunakan yaitu metode IndirectELISA dan Metode Double Antibody SandwichELISA (DAS-ELISA).

Metode Indirect-ELISA (I-ELISA). Metode I-ELISA digunakan untuk mendeteksi CMV, SqMV, dan ZYMV, dengan pengenceran berturut-turut $1: 200,1$ : 200, $1: 1000$ (Agdia, US) mengikuti metode Dijkstra \& de Jager (1998). Kontrol negatif digunakan dari ekstrak tanaman mentimun sehat sedangkan kontrol positif merupakan ekstrak tanaman mentimun yang terinfeksi oleh virus yang sesuai (Agdia, US). Nilai absorbansi hasil ELISA dibaca menggunakan ELISA reader model 550 (Bio-Rad, US) dengan panjang gelombang $405 \mathrm{~nm}$ pada 30 sampai 60 menit setelah penambahan cairan substrat. Hasil ELISA dinyatakan positif jika nilai absorbansi sampel 2 kali lebih besar dari nilai absorbansi kontrol negatif (Matthews, 1993).

Metode Double Antibody Sandwich-ELISA (DAS-ELISA). Metode DAS-ELISA digunakan untuk mendeteksi TRSV dan WMV dengan pengenceran masing-masing 1:1000 (DSMZ, DE) mengikuti metode 
Clark \& Adams (1977). Pembacaan nilai absorbansi hasil ELISA dilakukan seperti diuraikan sebelumnya.

\section{Deteksi Menggunakan Metode Polymerase Chain Reaction (PCR)}

Deteksi Begomovirus dilakukan dengan metode PCR karena sulitnya mendapatkan titer virus yang cukup, disebabkan sifat fisik dan kimia partikel virus sehingga sulit dimurnikan dalam bentuk stabil (Roberts et al., 1984). Tahapan deteksi terdiri dari (1) ekstraksi DNA total tanaman, (2) amplifikasi DNA target, dan (3) visualisasi hasil amplifikasi DNA. Ekstraksi DNA total tanaman mentimun menggunakan metode Doyle \& Doyle (1987) yang dimodifikasi. DNA hasil ekstraksi digunakan sebagai templat pada tahap amplifikasi dengan teknik PCR menggunakan pasangan primer universal Begomovirus yaitu pAL1v1978 (5'-GCATCTGCA GGCCCACATYGTCTTYCCNGT-3') dan pAR1c715 (5'-GATTTCTGCAGTTDATRTTYTCRTCCAT CCA-3') (Rojas et al. 1993). Reaksi PCR (total volum $25 \mu \mathrm{l})$ terdiri atas $16.3 \mu 1 \mathrm{H}_{2} \mathrm{O}, 2.5 \mu \mathrm{l}$ buffer $10 \mathrm{x}+\mathrm{Mg}^{2+}$, $0.5 \mu \mathrm{l}$ dNP10 mM, $1 \mu \mathrm{l}$ primer pAL1v1978 $10 \mathrm{mM}, 1$ $\mu \mathrm{l}$ primer pAR1c $71510 \mathrm{mM}, 2.5 \mu \mathrm{l}$ sucrose cresol 10x, $0.2 \mu l$ Dream Taq DNA polymerase (Promega, Madison, WI), dan $1 \mu 1$ sampel DNA. Program amplifikasi dilakukan sebanyak 35 siklus, yang terdiri dari denaturasi pada suhu $94{ }^{\circ} \mathrm{C}$ selama 1 menit, penempelan primer (annealing) pada suhu $50{ }^{\circ} \mathrm{C}$ selama 1 menit, dan pemanjangan primer (extension) pada suhu $72{ }^{\circ} \mathrm{C}$ selama 1 menit. Hasil amplifikasi DNA dianalisis dengan elektroforesis pada gel agarosa $1 \%$, dan visualisasi pita DNA dilakukan pada $U V$ transilluminator.
Perunutan Basa Nukleotida dan Analisis Keragaman Genetik. Fragmen DNA hasil amplifikasi dikirim ke DNA Sequencing BioSM Laboratories Malaysia untuk perunutan nukleotida. Urutan nukleotida yang diperoleh kemudian digunakan untuk analisis tingkat homologinya dengan isolat-isolat Begomovirus lainnya yang terdapat di GenBank menggunakan perangkat Blast (www.ncbi.nlm.nih.gov).

\section{HASIL DAN PEMBAHASAN}

\section{Pengumpulan Sampel Tanaman Mentimun} Terinfeksi Begomovirus. Pengamatan penyakit di daerah Bogor dan Subang (Jawa Barat), Tegal dan Sukoharjo (Jawa Tengah), serta Sleman (Daerah Istimewa Yogyakarta) menunjukkan adanya variasi gejala pada pertanaman mentimun. Gejala yang terlihat pada pertanaman mentimun di daerah Bogor dan Subang memiliki beberapa perbedaan. Tanaman mentimun yang berada di Bogor menunjukkan gejala daun mengeriting, buah mengalami perubahan bentuk, ukuran daun dan buah menjadi lebih kecil dibandingkan ukuran normal (Gambar 1). Namun, gejala pada tanaman mentimun yang berada di Kasomalang, Subang berupa penebalan pada daerah tulang daun dengan warna hijau tua, sedangkan bagian lamina daun berwarna hijau muda, dan tepi daun berwarna kuning. Gejala ini sedikit berbeda pada tanaman mentimun yang berada di Pagaden Barat (Subang), yaitu gejala kuning pada bagian lamina daun.

Pertanaman mentimun di daerah Jawa Tengah dan DI Yogyakarta menunjukkan beberapa kemiripan gejala. Tanaman mentimun di kabupaten Tegal
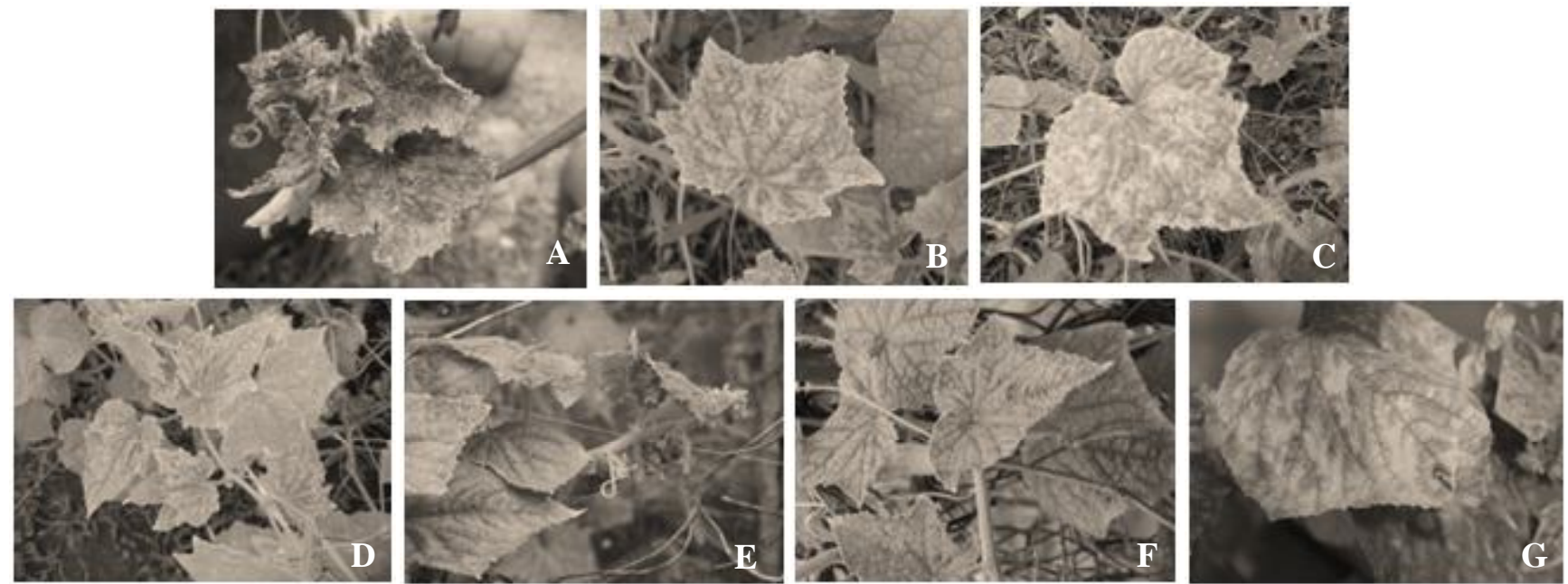

Gambar 1. Penyakit daun keriting kuning pada mentimun dari beberapa daerah yang menunjukkan variasi gejala: Situgede - Bogor (A), Dukuhwaru - Tegal (B), Kalasan - Sleman (C), Ngemplak - Sleman (D), Kasomalang - Subang (E), Pagaden Barat - Subang (F), Baki - Sukoharjo (G). 
menunjukkan gejala mosaik kuning pada bagian lamina daun, penebalan tulang daun sehingga berwarna hijau tua, dan berkurangnya ukuran daun. Gejala ini mirip seperti gejala yang terdapat pada tanaman mentimun di daerah Kalasan (Sleman), namun daun mentimun yang terdapat di Kalasan juga mengalami pelepuhan sehingga permukaan daun menjadi tidak rata. Sampel yang berasal dari Ngemplak (Sleman) berbeda dengan sampel asal Kalasan, yaitu tidak mengalami pelepuhan.

Variasi Gejala. Variasi gejala yang ditemukan pada pertanaman di lapangan dapat disebabkan beberapa faktor, diantaranya dipengaruhi oleh infeksi oleh lebih dari satu jenis virus atau infeksi campuran. Syller (2012) menyatakan pada infeksi campuran beberapa virus terjadi interaksi dua virus atau lebih yang menginduksi gejala lebih parah karena interaksi tersebut meningkatkan replikasi virus. Renteria-Canet et al. (2011) menambahkan bahwa infeksi campuran menjadi masalah penting karena merupakan sumber potensial dari keragaman Geminivirus. Hal ini disebabkan terjadinya rekombinasi yang menghasilkan varian atau bahkan spesies virus baru. Infeksi campuran menyebabkan gejala yang lebih parah, misalnya pertumbuhan apikal tanaman berhenti karena jaringan apeks tidak lagi membelah. Infeksi campuran dapat berupa interaksi aditif, sinergis, dan antagonis. Interaksi sinergis menyebabkan gejala lebih parah dibandingkan dengan infeksi virus secara tunggal (Pita et al., 2001). Faktor-faktor yang mempengaruhi interaksi tersebut antara lain tipe dan umur tanaman inang, serta urutan infeksi virus (Mendez-Lozano et al., 2003).
Variasi gejala tersebut muncul sebagai respon tanaman dan dipengaruhi oleh kerentanan setiap varietas (genotip) tanaman terhadap virus maupun serangga vektornya (Matthews, 1992). Tanaman mentimun di Bogor merupakan varietas Bandana yang menunjukkan gejala lebih keriting, sedangkan tanaman mentimun varietas Baby di Tegal menunjukkan daun menguning tanpa adanya gejala keriting. Sementara itu, tanaman mentimun di Subang merupakan varietas Sabana dan hanya menunjukkan gejala mosaik dan menguning. Matthews (1992) menambahkan bahwa variasi gejala yang muncul juga dipengaruhi oleh faktor tanaman seperti umur tanaman. Daun tanaman mentimun yang berasal dari Subang masih sangat muda, sehingga gejala yang tampak tidak terlalu jelas. Gejala penyakit keriting kuning yang jelas tampak pada sampel daun mentimun dari Bogor, Tegal, dan Sleman. Selain dari faktor tanaman, variasi gejala juga dipengaruhi oleh faktor lingkungan seperti tingkat kesuburan tanah dan iklim di sekitar tanaman (Sudiono et al., 2005). Kondisi lingkungan seperti suhu, kelembaban, dan curah hujan di daerah Tegal, Sukoharjo, Sleman, dan Bogor berbeda-beda. Hal tersebut dapat mempengaruhi respon tanaman mentimun terhadap infeksi beberapa virus yang ditunjukkan dengan adanya gejala yang bervariasi.

Deteksi Virus. Infeksi Begomovirus, SqMV, ZyMV, dan CMV ditemukan pada hampir semua sampel, namun infeksi TRSV dan WMV tidak ditemukan pada semua sampel (Tabel 1). Infeksi SqMV, ZyMV, dan CMV banyak dilaporkan terjadi pada tanaman Cucurbitaceae. Ketiga virus memiliki kisaran inang yang luas dan dapat ditularkan oleh lebih dari satu jenis serangga vektor, juga

Tabel 1. Hasil deteksi beberapa jenis virus dan karakter gejala pada tanaman mentimun di Bogor dan Subang (Jawa Barat), Tegal dan Sukoharjo (Jawa Tengah), serta Sleman (Daerah Istimewa Yogyakarta)

\begin{tabular}{lccccccc}
\hline Sampel daun asal & Begomovirus & SqMV & ZyMV & CMV & TRSV & WMV & Karakter gejala $^{\mathrm{a}}$ \\
\hline Situgede (Bogor) & + & + & + & + & - & - & Mo, K, Ml, Kc \\
Dukuhwaru (Tegal) & + & + & - & - & - & - & Mo, Mk, Vb \\
Kalasan (Sleman) & + & + & + & + & - & - & Mo, Mk, Ml \\
Ngemplak (Sleman) & + & + & + & + & - & - & Mo, Mk, Vb \\
Baki (Sukoharjo) & + & - & - & + & - & - & Mo, Mk, Vb \\
Kasomalang (Subang) & - & + & + & + & - & - & Mo, Mk, Vb \\
Pagaden Barat (Subang) & - & + & + & + & - & - & Mo, Vb \\
\hline
\end{tabular}

Keterangan: (+), sampel memberikan reaksi positif; (-), sampel memberikan reaksi negatif; SqMV, Squash mosaic comovirus; ZyMV, Zuchini mosaic potyvirus, CMV, Cucumber mosaic comovirus; TRSV, Tobacco ringspot potyvirus; WMV, Watermelon mosaic potyvirus ${ }^{a}$ Karakter gejala: Mo, mosaik; Mk, menguning; Ml, melepuh; K, keriting; $\mathrm{Vb}$, vein banding; Kc, daun mengecil 
secara mekanis melalui alat pertanian sehingga dapat menyebar dengan cepat (Zitter \& Murphy 2009, Sikora 2004; Coutts 2006). Beberapa penelitian sebelumnya melaporkan infeksi TRSV dan WMV sering ditemukan pada tanaman Cucurbitaceae. Kedua virus dapat tertular secara mekanis dan TRSV dapat terbawa benih pada tanaman mentimun (Coutts, 2006; Sikora, 2004). Namun, kedua virus tersebut tidak terdeteksi pada penelitian ini kemungkinan karena konsentrasi kedua virus sangat rendah dibandingkan SqMV, ZyMV, dan CMV.

Provvidenti (1996) melaporkan sekitar 32 virus berbeda menginfeksi tanaman Cucurbitaceae di dunia. Seperti diuraikan di atas, infeksi campuran beberapa virus dapat menyebabkan munculnya gejala yang lebih parah (Renteria-Canet et al., 2011). Hal ini tampak pada sampel asal Bogor dan Sleman (Kalasan dan Ngemplak) yang terinfeksi oleh 5 virus (Begomovirus, SqMV, ZyMV, dan CMV) secara bersamaan menunjukkan gejala yang lebih parah dibandingkan sampel lainnya yaitu berupa daun keriting, mosaik, menguning, dan melepuh.

Deteksi penyebab penyakit daun keriting kuning pada sampel mentimun dengan teknik PCR menggunakan pasangan primer pAL1v1978/pAR1c715 menunjukkan adanya pita DNA berukuran 1600 pasang basa pada sampel mentimun yang berasal dari Tegal, Sleman (Kalasan dan Ngemplak), serta Bogor (Gambar 2). Fragmen DNA tersebut merupakan DNA spesifik Begomovirus, sehingga membuktikan bahwa sampelsampel tanaman mentimun tersebut terinfeksi Begomovirus. Pasangan primer yang sama (pAL1v1978/pAR1v715) telah digunakan untuk mendeteksi berbagai spesies Begomovirus, antara lain Tomato leaf curl virus pada tomat dan labu (Bela-ong \& Bajet, 2007), Okra yellow crinkle Mali virus pada tanaman okra (Abelmoschus esculentus) (Shih et al., 2006), Malvastrum yellow mosaic Jamaica virus pada gulma (Malvastrum americanum dan Sida spinosa) (Graham et al., 2006), dan Tobacco mottle leaf curl virus pada tanaman tembakau (Nicotiana tabacum) (Dominguez et al., 2008).

Kelima isolat yang berasal dari Tegal, Sleman (Kalasan dan Ngemplak), serta Bogor memiliki kemiripan basa nukleotida sangat tinggi $(95,7 \%$ hingga 98,6\%) dengan isolat Tomato leaf curl New Delhi virus-[Cucumber:Indonesia] (AB613825) (Tabel 2). Menurut Fauquet \& Stanley (2005), isolat Begomovirus yang memiliki kemiripan basa nukleotida lebih dari $89 \%$

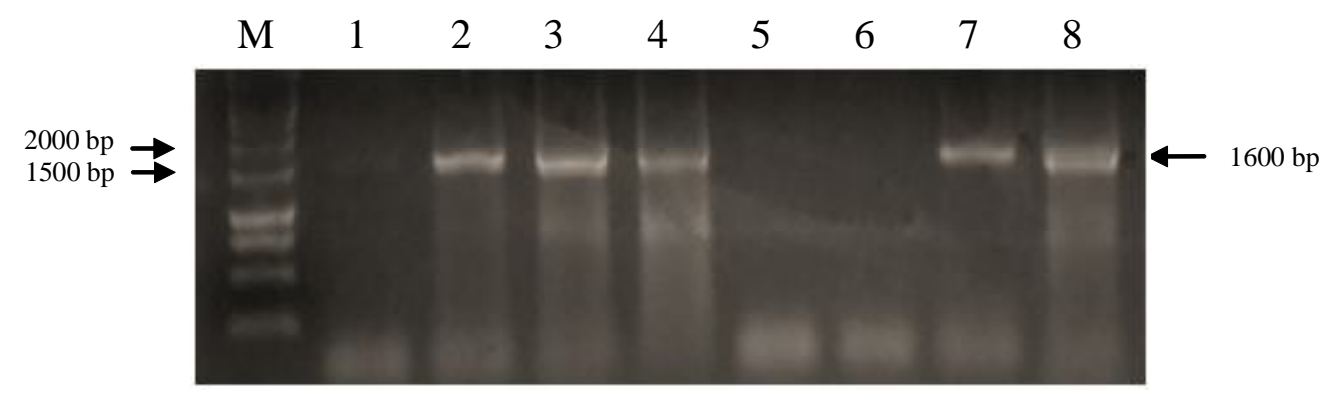

Gambar 2. Hasil amplifikasi PCR menggunakan pasangan primer pAL1v1978/pAR1c715. (M) penanda DNA $1 \mathrm{~kb}$ ladder (Fermentas, USA); (1) kontrol negatif (air); (2) isolat Tegal; (3) isolat Kalasan; (4) isolat Ngemplak; (5) isolat Kasomalang; (6) isolat Pagaden Barat; (7) isolat Bogor; (8) isolat Sukoharjo.

Tabel 2. Tingkat homologi (\%) isolat Begomovirus dengan isolat Tomato leaf curl New Delhi virus-[Cucumber] (TLCNDV-[Cuc]:AB613825)

\begin{tabular}{llcc}
\hline \multicolumn{1}{c}{ Asal isolat } & \multicolumn{1}{c}{ Tanaman inang } & Panjang basa nukleotida (bp) & Tingkat homologi (\%) \\
\hline Dukuhwaru (Tegal) & Cucumis sativus & 1592 & 98,4 \\
Kalasan (Sleman) & C. sativus & 1633 & 98,6 \\
Ngemplak (Sleman) & C. sativus & 1592 & 98,4 \\
Baki (Sukoharjo) & C. sativus & 1474 & 98,6 \\
Situgede (Bogor) & C. sativus & 1512 & 95,7 \\
\hline
\end{tabular}


termasuk dalam spesies virus yang sama. Hal tersebut menunjukkan bahwa kelima sampel merupakan isolat TLCV yang menginfeksi tanaman mentimun.

\section{SIMPULAN}

Penyakit daun keriting kuning dengan gejala mosaik kuning, keriting, dan melepuh pada mentimun di Jawa Barat, Jawa Tengah, dan Daerah Istimewa Yogyakarta disebabkan oleh Tomato leaf curl New Delhi virus, dan berasosiasi dengan infeksi Squash mosaic virus, Zucchini yellow mosaic virus, dan Cucumber mosaic virus.

\section{SANWACANA}

Penelitian ini merupakan bagian dari penelitian kerjasama antara Fakultas Pertanian Institut Pertanian Bogor dengan AusAID_funded Economic Cooperation Work Program of the ASEAN-AustraliaNew Zealand Free Trade Agreement. Penulis menyampaikan terima kasih kepada John Thomas (Department of Employment, Economic Development and Innovation Queensland Australia) atas fasilitas dan bantuan yang telah diberikan selama pelaksanaan penelitian ini.

\section{DAFTAR PUSTAKA}

Aidawati N, Hidayat SH, Suseno R, Hidayat P, \& Sujiprihati S. 2005. Identifikasi Geminivirus yang menginfeksi tomat berdasarkan pada teknik polymerase chain reaction-restriction fragment length polymorphim. Jurnal Mikrobiologi Indonesia 10(1): 29-32.

Bela-ong DB \& Bajet NB. 2007. Molecular detection of whitefly-transmissible Geminiviruses (family Geminiviridae, genus Begomovirus) in the Philippines. Philipp. J. Sci. 36(2): 87-101.

Clark MF \& Adams AN. 1977. Characteristics of the microplate method of enzyme-linked immunosorbent assay for the detection of plant viruses. J. Gen. Virol. 34(3): 475-483.

Coutts B. 2006. Virus disease of cucurbit crops. Farmnote. http://archive.agric.wa.gov.au/ objtwr/imported_assets/content/hort/veg/pw/ fn2006_viruscucurbits_bcoutts.pdf. [diakses 10 Jan 2014].
Dijkstra J \& de Jager CP. 1998. Practical Plant Virology. Protocol and Exercise. SpringerVerlag Berlin Heidelberg, Berlin.

Dominguez M, Ramos PL, Sanchez Y, Crespo J, Andino V, Pujol M, \& Borroto C. 2008. Tobacco mottle leaf curl virus, a new Begomovirus infecting tobacco in Cuba. New Dis. Rep. 18: 32.

Doyle JJ \& Doyle JL. 1987. A rapid DNA isolation procedure for small quantities of fresh leaf tissues. Phytochem. Bull. 19: 11-15.

Fauquet CM \& Stanley J. 2005. Revising the way we conceive and name viruses below the speies level: a review of Geminivirus taxonomy calls for new standardized isolate descriptions. Arch. Virol. 150: 2151.

Graham AP, Stewart CS, \& Roye ME. 2006. First report of a Begomovirus infecting two common weeds: Malvastrum americanum and Sida apinosa in Jamaica. New Dis. Rep.13: 44.

Hidayat SH, Chatchawankanpanich O, Rusli E, \& Aidawati N. 2006. Begomovirus associated with pepper yellow leaf curl disease in West Java, Indonesia. J. Indon. Microbiol. 11(2): 87-89.

Ito T, Sharma P, Kittipakorn K, \& Ikegami M. 2008. Complete nucleotide sequence of a new isolate of Tomato leaf curl New Delhi virus infecting cucumber, bottle gourd, and muskmelon in Thailand. Arch. Virol. 153: 611-613.

Matthews REF. 1993. Diagnosis of Plant virus disease. CRC Press, Florida.

Matthews REF. 1992. Fundamentals of Plant Virology. Academic Press Inc, San Diego.

Méndez-Lozano J, Torres-Pacheco I, Fauquet CM, \& Rivera-Bustamante RF. 2003. Interactions between geminiviruses in a naturally occurring mixture: Pepper huasteco virus and Pepper golden mosaic virus. Phytopathol 93: 270-277.

Mizutani T, Daryono BS, Ikegami M, \& Natsuaki KT. 2011. First report of Tomato leaf curl New Delhi virus infecting cucumber in Central Java, Indonesia. Plant Dis. 95(11): 1485. 
Pita JS, Fondong VN, Sangare A, Otim-Nape GW, Ogwal S, \& Fauquet CM. 2001. Recombination, pseudorecombination and synergism of geminiviruses are determinant keys to the epidemic of severe cassava mosaic disease in Uganda. J. Ge. Virol. 82: 655-665.

Provvidenti R. 1996. Disease Caused by Viruses. Compendium of Cucurbit Disease. The American Phytopathological Society Press, Minnesota.

Renteria-Canett IR, Xoconostle-Cazares B, RuizMedrano R, \& Rivera-Bustamante RF. 2011. Geminivirus mixed infection on pepper plants: Synergistic interaction between PHYVV and PepGMV. Virology Journal 8: 104-117.

Robert IM, Robinson DJ, \& Harrison BD. 1984Serological relationship and genome homologies among Geminiviruses. J. Gen Virol 65: 1723-1730.

Rojas MR, Gilbertson RL, Russeli DR, \& Maxwell DP. 1993. Use of degenerate primers in the polymerase chain reaction to detect whiteflytransmitted geminiviruses. Plant Dis. 77: 340347.

Samretwanich K, Chiemsombat P, Kittipakorn K, \& Ikegami M. 2000a. Tomato leaf curl geminivirus associated with cucumber yellow leaf disease in Thailand. J. Phytopathol. 148: 615-617.

Samretwanich K, Chiemsombat P, Kittipakorn K, \& Ikegami M. 2000b. Yellow leaf disease of cantaloupe and wax gourd from Thailand caused by Tomato leaf curl virus. Plant Dis. 84: 200.
Samretwanich K, Chiemsombat P, Kittipakorn K, \& Ikegami M. 2000c. Yellow leaf disease of muskmelon from Thailand caused by Tomato leaf curl virus. Plant Disease 84: 707.

Santoso TJ, Hidayat SH, Duriat AS, Herman M, \& Sudarsono. 2008. Identity and sequence diversity of Begomovirus associated with yellow leaf curl disease of tomato in Indonesia. Microbiology 2(1): $1-7$.

Shih SL, Green SK, Tsai WS, Lee LM, \& Levasseur V. 2006. First report of a distinct Begomovirus associated with okra yellow crinkle disease in Mali. New Disease Report 14: 45.

Sikora EJ. 2004. Plant Disease Notes: Mosaic virus of Cucurbits. Alabama Cooperative Extension System. http://www.aces.edu/pubs/docs/A/ANR0876/ANR-0876.pdf. [diaskes 1 Mar 2014].

Sudiono, Yasin N, Hidayat SH, \& Hidayat P. 2005. Penyebaran dan deteksi molekuler virus penyebab penyakit kuning pada tanaman cabai di Sumatera. J. HPT Tropika 2(5): 113-121.

Syller J. 2012. Facilitative and antagonistic interactions between plant viruses in mixed infections. Molecular Plant Pathology 13(2): 204-216.

Trisusilowati EB, Suseno R, Sosromarsono S, Barizi, Soedarmadi, \& Nur MA. 1990. Transmission, serological aspects, and morphology of the tobacco krupuk virus. Indonesian Journal of Tropical Agriculture 2(1): 75-79.

Zitter TA \& Murphy JF. 2009. Cucumber mosaic virus. The Plant Health Instuctor. DOI: 10.1094/PHII-2009-0518-01. [diaskes 1 Mar 2014]. 